\title{
HUBUNGAN TINGKAT KECEMASAN PERPISAHAN DENGAN ORANG TUA TERHADAP MOTIVASI BELAJAR SANTRI DIPONDOK PESANTREN DARUSSALAM DESA NGESONG SENGON JOMBANG
}

\author{
Heri Triwibowo, Khoirunnisyak
}

\begin{abstract}
Student life / of student at traditional muslim school while studying at muslim boarding school is full of difficulty. Starting from academic difficulty, financial difficulty, sociocultural difficulty, surroudings difficulty etc, the difficulties will be more felt for students or students at traditionsl muslim school who are far from family or come from om threats to know the realitiship of searation unkiety level with parents to motivations to learn students on traditional muslim school Darussalam, ngesong sengon village, Jombang. The research design that is used is correlational analysis of population in this research is of all students on traditional muslim scool in class 1 junior high school and 1 high school in Sengon Village Jombang, Jombang Regency with sample resources 80 people, the technique using total sampling Independent variable in this research is anxiety and dependent variable Is the motivation, Data Analysis, Editing, coding, scoring Tabulating and cross tabulation. Based on the results of research can be concluded than half of respondents have moderate anxiety as many us 51 people $(63.8 \%)$. Half of respondent's motivation is moderate as many us 40 people (50\%). The students on traditional muslim scool who have severe anxiety most 7 people (100\%) have a weak motivation. This means that the more severe anxiety, the weaker the motivation to learn in students on traditional muslim scool There is anxiety relationship Farewell to Parents about Motivation Learning Students In Darussalam boarding school Ngesong Sengon Village Jombang. The new students on traditional muslim enter the boarding school should be active in following the activities at the boarding school, developing hobby and follow extracurricular in boarding school .
\end{abstract}

Keywords: Anxiety, Parent, Learning Motivation

PENDAHULUAN 
Pondok pesantren merupakan asrama tempat tinggal para santri. Menurut Wahid, pondok pesantren mirip dengan akademi militer atau biara (monestory convent). Dalam arti bahwa mereka yang berada disana mengalami suatu kondisi totalitas.(Afif dan Gus Tohir, 2015). Kehidupan siswa/santri selama belajar di pondok pesantren itu penuh dengan kesulitan. Mulai dari kesulitan akademik, kesulitan finansial, kesulitan sosiokultural, kesulitan lingkungan dan sebagainya, Kesulitan- kesulitan tersebut akan lebih terasa bagi siswa/santri yang jauh dari keluarga atau berasal jauh dari luar kota. Hal ini akan memicu terjadi adanya kecemasan. Kecemasan adalah keteganggan yang dihasilkan dari ancaman terhadap keamanan, baik yang nyata mauapu imajinasi biasa (Hall dan Lindzey 2001, Trianto 2012).

Santri yang baru masuk dipondok pesantren sendiri akan lebih sering terjadi kecemasan tahun pertama pendidikannya di pesantren karena lingkungan barunya. Kecemasan merupakan faktor yang berpengaruh pada motivasi, karena individu yang mengalami kecemasan akan mengalami hambatan dalam menyelesaikan tugas-tugas atau mencapai tujuan yang telah ditetapkan. Pada tahap tertentu, kecemasan dapat meningkatkan motivasi dan kinerja, akan tetapi apabila kecemasan tersebut melampaui batas atau kemampuan individu untuk mengelolanya maka kecemasan melemahkan motivasi dan menurunkan kinerja (Rahmatika, 2014).

Data Riskesdas 2013 menyatakan bahwa prevalensi nasional gangguan kecemasan dialami oleh remaja di Indonesia yang berusia kurang lebih 15 tahun sekitar 37 ribu penduduk dengan prevalensi gangguan kecemasan pada remaja di Jawa Tengah tercatat sebanyak 4,7 \% (Depkes, 2013). Data departemen agama tahun 2010/2011 berhasil mendata 27,218 pondok pesantren yang terbesar diseluruh Indonesia. Populasi pondok pesantrean terbesar berada pada provinsi jawa barat, jawa timur, jawa tengah dan banten yang berjumlah $78,9 \%$ dari jumlah seluruh pondok pesantren di Indonesia. Jumlah santri pondok pesantren secara keseluruhan adalah 3.642.738 orang santri terdiri dari 1.895 .580 orang $(52,0 \%)$ santri laki-laki 1.747 .158 orang orang $(48,0 \%)$ santri perempuan (pendis.kemenag.2013). Pada siswa SMP mempunyai tingkat kecemasan yang lebih tinggi dengan prevalensi 68,3 \% dibandingkan siswa SMA dengan prevalensi 31,7\% (Harpell \& Andrews 2012). Hasil dari studi pendahuluan pada tanggal 26 April 2017 di pondok pesantren Darussalam jombang. Berdasarkan hasil wawancara dan dibagikan kuisoner DASS pada 10 santri. Ditemukan 5 santri dengan kriteria cemas ringan. 4 santri dengan kriteria cemas sedang, 1 santri dengan kriteria cemas berat. Dari segi motivasi belajar, mereka mengatakan masih merasa khawatir akan perpisahan dengan orang tua dengan keadaan lingkungan yang berbeda dan karena kekhawatiran tersebut mereka kurang konsentrasi dalam belajar.

Sebagaimana penelitian yang dilakukan oleh Rahmatika (2014) menunjukan bahwa 43,8 \% santri tingkat SMP Pondok Pesantren Asshiddiqiyah Kebun Jeruk Jakarta mengalami kecemasan tinggi akibat perpisahan dengan orang tua nya.

Kondisi yang menyebabkan remaja mengalami kecemasan adalah ketika memasuki pesantren/sekolah yang baru, beban tugas sekolah yang padat, dan adanya perasaan malu terhadap lingkungan sosialnya. Kecemasan yang dialami oleh remaja siswa SMP biasanya berkaitan dengan pembelajaran yang diberikan disekolah. Selain siswa SMP yang bersekolah di sekolah konvensional, kecemasan juga bisa dialami oleh siswa SMP yang bersekolah di pondok pesantren. Selain kecemasan timbul karena tugas sekolah, kecemasa juga timbul akibat perpisahan dengan orang tuanya, mereka belum mampu beradaptasi dan memiliki motivasi belajar yang kurang (Aminullah,2013).

Banyak hal yang dapat dilakukan untuk menghindari kecemasan terhadap motivasi belajar dipondok pesantren salah satunya adalah peer monitoring, mengenal, bicara dan mendampingi santri dalam masalah kesulitan 
pelajaran yang diperolehnya agar motivasi belajarnya tidak menurun. Membangkitkan self-competition dengan jalan menimbulkan perasaan puas terhadap hasil-hasil dan prestasi yang telah mereka capai betapapun kecil atau sedikitnya hasil yang dicapai. (purwanto ngalim 2013).

Berdasarkan latar belakang diatas maka penulis tertarik untuk melakukan penelitian tentang "hubungan antara kecemasan perpisahan dengan orang tua terhadap motivasi belajar santri dipondok Darussalam desa Ngesong Sengon Jombang".

\section{METODE}

Desain penelitian yang digunakan adalah analitik correlational dengan pendekatan cross sectional yaitu jenis penelitian yang menekankan waktu pengukuran atau observasi data variable independen dan dependen hanya satu kali pada satu saat. Pada penelitian ini populasi nya yaitu semua santri yang duduk di kelas 1 SMP dan 1 SMA di Desa Sengon Kecamatan jombang Kabupaten Jombang sebanyak 80 santri. Teknik sampling dalam penelitian ini menggunakan total sampling. Dikatakan Total sampling adalah teknik pengambilan sampel dengan memasukkan seluruh anggota populasi untuk menjadi sampel penelitian. Sampel pada penelitian ini adalah seluruh santri yang duduk di kelas 1 SMP dan 1 SMA di Desa Sengon Kecamatan jombang Kabupaten Jombang sebanyak 80 santri. Variabel independen dalam penelitian ini adalah kecemasan dan variabel dependen adalah adalah motivasi belajar. Metode pengumpulan data menggunakan kuisioner kecemasan DASS dan kuisioner motivasi belajar yang pernah dibuat penelitian oleh Rahmatika 2014 yang berjudul hubungan tingkat kecemasan terhadap motivasi belajar. Kuesioner diberikan langsung kepada responden. Lokasi penelitian dilaksanakan di Pondok Pesantren Darussalam kabupaten Jombang 2017. Analisa data pada penelitian ini menggunakan crosstabulation.
Tabel 1. Karakteristik Responden Berdasarkan Umur

\begin{tabular}{llll}
\hline No & Umur & Jumlah & $\begin{array}{l}\text { Persentase } \\
(\mathbf{\%})\end{array}$ \\
\hline & & & \\
1. & 13 Tahun & 25 & 31.2 \\
2. & 14 Tahun & 8 & 10.0 \\
3. & 16 Tahun & 43 & 53.8 \\
4. & 17 Tahun & 4 & 5.0 \\
\hline & Total & 80 & 100.0 \\
\hline
\end{tabular}

Berdasarkan tabel 1 dapat menunjukkan bahwa setengah responden berusia 13 tahun sebanyak 25 orang (31.2\%).

Tabel 2. Karakteristik Responden Berdasarkan Pendidikan

\begin{tabular}{llll}
\hline No & Pendidikan & Jumlah & $\begin{array}{l}\text { Persentase } \\
(\mathbf{\%})\end{array}$ \\
\hline 1. & SMA & 33 & 41.2 \\
2. & SMP & 47 & 58.8 \\
\hline & Total & 80 & 100.0 \\
\hline
\end{tabular}

Berdasarkan tabel 2 dapat menunjukkan bahwa sebagian besar responden berpendidikan SMP sebanyak 47 orang $(58,8 \%)$.

Tabel 3. Karakteristik Responden Berdasarkan Kecemasan Perpisahan Dengan Orang Tua

\begin{tabular}{llcc}
\hline No & $\begin{array}{c}\text { Kecemasan } \\
\text { perpisahan } \\
\text { dengan } \\
\text { orang tua }\end{array}$ & Jumlah & $\begin{array}{c}\text { Persentase } \\
\text { (\%) }\end{array}$ \\
\hline 1. & Ringan & 22 & 27.5 \\
2. & Sedang & 51 & 63.8 \\
3. & Berat & 7 & 8.7 \\
\hline & Total & 80 & 100.0 \\
\hline
\end{tabular}

Berdasarkan tabel 3 dapat menunjukkan bahwa lebih dari setengah responden memiliki kecemasan sedang sebanyak 51 orang $(63,8 \%)$

\section{HASIL}


Tabel 4. Karakteristik Responden Berdasarkan Motivasi Belajar

\begin{tabular}{llll}
\hline No & Motivasi & Jumlah & $\begin{array}{l}\text { Persentase } \\
(\mathbf{\%})\end{array}$ \\
\hline 1. & Kuat & 29 & 36.2 \\
2. & Sedang & 40 & 50.0 \\
3. & Lemah & 11 & 13.8 \\
\hline & Total & 80 & 100.0 \\
\hline
\end{tabular}

Berdasarkan tabel 4 dapat menunjukkan bahwa setengah motivasi responden adalah sedang sebanyak 40 orang $(50 \%)$.

Tabel 5. Tabulasi Silang Kecemasan Perpisahan dengan Orang Tua Terhadap Motivasi Belajar Santri Dipondok Pesantren Darussalam Desa Ngesong Sengon Jombang

\begin{tabular}{|c|c|c|c|c|}
\hline & & Motivas & & \\
\hline $\begin{array}{l}\text { Kece } \\
\text { masa }\end{array}$ & Kuat & $\begin{array}{l}\text { Sedan } \\
\mathrm{g}\end{array}$ & $\begin{array}{l}\text { Lema } \\
\text { h }\end{array}$ & Total \\
\hline
\end{tabular}

\begin{tabular}{lllllllll} 
& $\sum$ & $\%$ & $\sum$ & $\%$ & $\sum$ & $\%$ & $\sum$ & $\%$ \\
\hline Ring & 1 & 8 & 3 & 1 & 0 & 0, & 2 & 100 \\
an & 9 & 6, & & 3, & & 0 & 2 & \\
& & 4 & & 6 & & & & \\
Seda & 1 & 1 & 3 & 7 & 4 & 7, & 4 & 100 \\
ng & 0 & 9, & 7 & 2, & & 8 & & \\
& & 6 & & 5 & & & & \\
Berat & 0 & 0 & 0 & 0 & 7 & 1 & 7 & 100 \\
& & & & & & 0 & & \\
& & & & & & 0 & & \\
\hline Tota & 2 & 3 & 4 & 5 & 1 & 1 & 8 & 100 \\
l & 9 & 6, & 0 & 0, & 1 & 3, & 0 & \\
& & 2 & & 0 & & 8 & & \\
\hline
\end{tabular}

Berdasarkan tabel 5 diketahui bahwa terdapat 7 responden yang mempunyai kecemasan berat sebagian besar 7 orang $(100 \%)$.

\section{PEMBAHASAN}

Kecemasan dengan orang tua

Berdasarkan tabel 3 dapat menunjukkan bahwa lebih dari setengah responden memiliki kecemasan sedang sebanyak 51 orang $(63,8 \%)$. Kecemasan merupakan perasaan yang menetap berupa kekuatan atau kecemasan (was-was, khawatir dan cemas) yang merupakan respon terhadap ancaman yang akan datang. Dianggap berbahaya atau hal tersebut dapat merupakan perasaan yang ditekan kedalam bawah alam sadar bila terjadi peningkatan akan adanya bahaya dari dalam (Ibrahim 2007). Kecemasan adalah bentuk perasaan khawatir, gelisah dan perasaan-perasaan lain yang kurang menyenangkan. Perpisahan dengan orang tua untuk memasuki lingkungan baru memang memerlukan waktu untuk beradaptasi rasa takut, khawatir tentunya dimiliki semua santri yang baru masuk di lingkungan pesantren, santri yang biasa mendapat perhatian lebih dirumah dari orang tua, di lingkungan pesantren harus hidup mandiri. Banyak faktor yang mempengaruhi kecemasan diantranya umur, pendidikan.

Kecemasan santri di pesantren dipengaruhi oleh umur. Dimana Berdasarkan tabel 1 dapat menunjukkan bahwa setengah responden berusia 13 tahun sebanyak 25 orang $(31.2 \%)$. Usia adalah umur yang terhitung mulai saat dilahirkan sampai saat ia akan berulang tahun. Semakin cukup umur, tingkat kematangan dan kekuatan seseorang akan lebih matang dalam berpikir dan bekerja. Dari segi kepercayaan masyarakat yang lebih dewasa akan lebih dipercaya dari pada orang yang belum cukup tinggi tingkat kedewasaannya. Hal ini sebagai akibat dari pengalaman dan kematangan jiwanya. kecemasan yang didukung oleh lingkungan berdasarkan kematangan atau usia seseorang. Umur merupakan ukuran tingkat kedewasaan seseorang (Purwanto, 2010). Umur akan mempengaruhi tingkat kematangan seseorang. Umur responden dalam kategori remaja awal merupakan umur perkembangan di mana pada usia tersebut remaja belum mampu cepat beradaptasi dengan lingkungan. Di samping itu Semakin bertambahnya umur seseorang maka orang tersebut semakin matang dalam berpikir secara rasional tentang dan lebih dapat beradaptasi dengan lingkungan.

Faktor lain yang mempengaruhi kecemasan adalah faktor pendidikan Dimana sebagian besar responden berpendidikan SMP sebanyak 47 orang $(58,8 \%)$.Teori yang dikemukakan oleh Notoatmodjo (2012), menyatakan bahwa Pendidikan berarti bimbingan yang diberikan oleh seseorang terhadap perkembangan orang lain menuju kearah suatu cita-cita tertentu. Makin tinggi tingkat pendidikan seseorang maka maka makin mudah dalam menerima informasi, sehingga semakin banyak pula pengetahuan yang dimiliki. Sebaliknya pendidikan yang kurang akan menghambat perkembangan sikap 
seseorang terhadap nilai-nilai yang baru dikenal. Pendidkan klien dapat meningkatkan keteraturan, sepanjang bahwa pendidikan tersebut merupakan pendidikan yang aktif. Pendidikan yang dasar membuat santri sulit dalam menerima informasi yang berhubungan adaptasi seperti peraturan dipesantren adaptasi di samping itu dengan lingkungan pesantren yang baru proses penyesuain diri harus dilakukan secara perlahan dan memerlukan proses sehingga responden sering mengalami kecemasan dengan hal-hal baru yang dialami.

Motivasi belajar santri

Berdasarkan tabel 4 dapat menunjukkan bahwa setengah motivasi responden adalah sedang sebanyak 40 orang (50\%). Motivasi adalah perubahan energi dalam diri seseorang yang ditandai dengan munculnya feeling dan di dahului dengan tanggapan terhadap adanya ujian. Motivasi juga dapat dikatakan serangkaian usaha untuk menyediakan kondisi-kondisi tertentu, sehingga seseorang mau dan ingin melakukan sesuatu (Sardiman, 2007). motivasi ialah untuk menggerakkan atau memacu para siswanyaagar timbul keinginan dan kemauanya untuk meningkatkan prestasi belajarnya sehingga tercapai tujuan pendidikan sesuai dengan yang diharapkan dan ditetapkan dalam kurikulum sekolah (Purwanto, 2013). Pada awal masuk pesantren siswa banyak diisi oleh kegiatan keagamaan di samping itu proses penyesuain diri dengan lingkungan yang sebagian besar mandiri menyebabkan para santri baru tidak memiliki waktu banyak untuk belajar, dan lingkungan social seperti banyaknya santri yang memiliki sifat-sifat dan tingkah laku yang kurang menyenangkan teman lain, mempunyai rasa rendah diri, dan dikucilkan dari kelompok dan pada akirnya akan berpengaruh pada kegiatan belajarnya. Faktor yang mempengaruhi motivasi belajar yaitu umur, kondisi lingkungan.

Berdasarkan tabel 1 dapat menunjukkan bahwa setengah responden berusia 13 tahun sebanyak 25 orang $(31.2 \%)$. Usia adalah umur yang terhitung mulai saat dilahirkan sampai saat ia akan berulang tahun. Semakin cukup umur, tingkat kematangan dan kekuatan seseorang akan lebih matang dalam berpikir dan bekerja. Dari segi kepercayaan masyarakat yang lebih dewasa akan lebih dipercaya dari pada orang yang belum cukup tinggi tingkat kedewasaannya. Hal ini sebagai akibat dari pengalaman dan kematangan jiwanya (Notoatmodjo, 2011). Umur para santri yang masih mudah menyebabkan para santri tidak dapat berfikir secara matang, para santri tidak dapat mengatur waktu, Umur merupakan ukuran tingkat kedewasaan seseorang. Orang yang mempunyai umur produktif akan mempunyai daya pikir yang lebih rasional dan memiliki pengetahuan yang baik sehingga orang memiliki motivasi yang baik.

Hubungan kecemasan Perpisahan dengan Orang Tua Terhadap Motivasi Belajar Santri

Berdasarkan tabel 5 diketahui bahwa terdapat 7 responden yang mempunyai kecemasan berat sebagian besar 7 orang $(100 \%)$ memiliki motivasi lemah. Artinya semakin berat kecemasan maka semakin lemah motivasi belajar pada santri.

Berdasarkan tabulasi silang dapat ditarik kesimpulan yaitu bahwa semakin berat cemas perpisahan dengan Orang Tua maka semakin lemah motivasi belajar santri. Pondok pesantren merupakan asrama tempat tinggal para santri. Menurut Wahid, pondok pesantren mirip dengan akademi militer atau biara (monestory convent). Dalam arti bahwa mereka yang berada disana mengalami suatu kondisi totalitas.(Afif dan Gus Tohir, 2015). Kehidupan siswa/santri selama belajar di pondok pesantren itu penuh dengan kesulitan. Mulai dari kesulitan akademik, kesulitan finansial, kesulitan sosiokultural, kesulitan lingkungan dan sebagainya, Kesulitankesulitan tersebut akan lebih terasa bagi siswa/santri yang jauh dari keluarga atau berasal jauh dari luar kota. Hal ini akan memicu terjadi adanya kecemasan. Kecemasan adalah keteganggan yang dihasilkan dari ancaman terhadap keamanan, baik yang nyata mauapu imajinasi biasa.

Menurut Davis (2013) kehadiran para santri dilingkungan yang baru akan mempengaruhi motivasi belajar siswa, Selain itu motivasi mengikuti pelajaran di sekolah juga dipengaruhi oleh kondisi cemas para santri pada lingkungan pesantren yang baru kondisi tekanan fisik dan psikis akibat adanya tuntutan kemandirian dalam lingkungan baru menyebabkan rasa cemas pada setiap kegiatan yang dilakukan di pesantren. Perubahan yang terjadi ini harus secara relatif bersifat menetap dan tidak hanya terjadi pada perilaku yang saat ini nampak, tetapi juga pada perilaku yang mungkin terjadi di masa datang, perubahan- 
perubahan tersebut terjadi karena adanya pengalaman, kurangnya motivasi belajar anak di karenakan faktor orang tua, lingkungan yang terkadang tidak mendukung anak dalam proses belajar Keberhasilan belajar secara teratur akan merupakan umpan balik bagi seseorang untuk kemudian akan membiasakan belajar lebih terarah dan teratur. Kesulitan belajar bukanlah suatu diagnosis tunggal semata-mata, melainkan terdiri dari berbagai jenis gangguan dengan berbagai macam gejala, penyebab, pengobatan dan perjalanan penyakit. Tidak semua problem belajar merupakan suatu kesulitan belajar. Ada anak yang menunjukkan perkembangan suatu keahlian tertentu lebih lambat daripada anak lain seusianya dan sebaliknya, tetapi masih dalam batas kewajaran.

Ada sebagian responden yang memiliki kecemasan sedang tetap memiliki motivasi kuat untuk tetap belajar, hal tesebut di karenakan orang tua telah memberikan informasi tentang tatacara kehidupan di pesantren, orang tua senantiasa menerapkan pola hidup mandiri pada anak. serta anak mampu untuk beradaptasi dengan cepat mengikuti tata cara di pesantren. Disamping itu para guru di pesantren senantiasa mendampingi santri berkomunikasi untuk melakukan aktivitas sehari-hari serta belajar dengan cara membengkitkan self competition dengan jalan menimbulkan perasaan puas terhadap sekecil apapun usaha yang dilakukan santri. Dan ada sebagian responden yang memiliki kecemasan sedang tetap memiliki motivasi lemah untuk belajar, hal tersebut dikarnakan orang tua mendukung /mendorong meningkatnya performa pada diri individu tersebut. Akan tetapi dorongan kebutuhan belajar dan harapan akan cita - cita kurang dan membuat motivasi belajarnya melemah.

\section{SIMPULAN}

Lebih dari setengah responden memiliki kecemasan sedang sebanyak 51 orang $(63,8 \%)$. Setengah motivasi responden adalah sedang sebanyak 40 orang $(50 \%)$. Santri yang memiliki kecemasan berat sebagian besar 7 orang $(100 \%)$ memiliki motivasi lemah. Artinya semakin berat kecemasan maka semakin lemah motivasi belajar pada santri. Ada hubungan kecemasan Perpisahan dengan Orang Tua Terhadap Motivasi Belajar Santri
Dipondok Pesantren Darussalam Desa Ngesong Sengon Jombang

\section{SARAN}

Hendaknya Responden dapat menyesuaikan diri dengan lingkungan pesantren, dapat berinteraksi dengan baik dam memiliki motivasi belajar yang kuat sehingga dapat berprestasi. Dengan cara selalu aktif mengikuti kegiatan dipondok pesantren, mengembangkan hobi dan mengikuti ekstrakulikuler yang ada dipondok pesantren.

Bagi pengasuh Pondok pesantren hendaknya mengadakan bimbingan konseling, mengenal, bicara dan mendampingi santri dalam masalah kesulitan pelajaran yang diperolehnya agar motivasi belajarnya tidak menurun.

Bagi orang tua Saat berkunjung hendaknya orang tua selalu memotivasi, membimbing, mengarahkan yang terbaik untuk anaknya, agar motivasinya meningkat.

\section{DAFTAR PUSTAKA}

Afif Abdullah Dan Antoro Masaji. 2015. Kumpulan Tanya Jawab Keagamaan. Yogyakarta: Pustaka Ilmu Sunni Salafiyah-KTB

Aminullah, M. Afif. 2013. Kecemasan Antara Siswa SMP Dan Santri Pondokpesantren.Vol.1.Http://Ejournal. Umm.Ac.Id/Index.Php/Jipt/Article/View /1578.Diakses Pada Tanggal 02 Oktober 2013. Pukul 20.43

Djali. 2009. Psikologi Pendidikan. Jakarta: Pt Bumi Aksara

Djamarah Sayiful Bahri.2011. Psikologi Belajar. Jakarta: Rineka Cipta Efendi Nursalam Feryy. 2008. Pendidikan Dalam Keperawatan Jakarta: Bumi Aksara Hamzah. 2008. Teori Motivasi Dan Pengukurannya. Jakarta: Bumi Aksara Hidayat. 2010. Metodologi Penelitian Kebidanan Dan Teknik Analisa Data. Jakarta: Salemba Medika

Ibrahim Ayub Sani, 2007, Panik Neurosis Gangguan Cemas. Jakarta: Dua AS-AS LPPM Stikes Bina Sehat Ppni Mojokerto 2016. Buku Panduan Penyusunan Skripsi

Lukluk A, Z Dan Bandiyah Siti. 2011 .Psikologi Kesehatan. Yogyakarta: Nuha Medika

Notoatmojo,S. 2012. Metodologi Penelitian Kesehatan. Jakarta: Rineka Cipta 
Nursalam. 2013. Metodologi Penelitian Ilmu Keperawatan. Jakarta: Salemba Medika

Oltmans T, F Dan Emery R, E. 2013. Psikologi Abnormal. Yogyakarta: Pustaka Pelajar

Purwanto M, N ， 2013, Psikologi Pendidikan. Bandung : PT. Remaja Rosda Karya

Rahmatika. 2014. Hubungan Tingkat Kecemasan Perpisahan Orang Tua Terhadap Motivasi Belajar Santri Pondok Pesantren Asshidqya KebunJerukjakarta.Http://Repositor y.Uinjkt.Ac.Id/Dspace/Handle/123 $456789 / 24087$ Diakses Pada

Tanggal 5 Maret 2014

Safaria Trianto. 2012. Manajemen Emosi. Jakarta: Bumi Aksara

Sardiman.2007 Intraksi Dan Motivasi Belajar Mengajar. Jakarta: PT. Raja Grafindo Persada.

Setiadi. 2013. Konsep Dan Praktik Penulisan Riset Keperawatan. Edisi 2. Yogyakarta: Graha Ilmu

Slameto. 2010. Belajar Dan Faktor-Faktor Yang Mempengaruhi. Jakarta: Rineka Cipta Struat Gail W. 2016. Keperawatan Kesehatan Jiwa. Jakarta:EGC

Sulistyaningsih. (2012). Metodologi Penelitian Kebidanan Kuatitatif-Kualitatif. Edisi I. Yogyakarta. Penerbit Geraha Ilmu

Suryono. 2010. Kumpulan Instrument Penelitian Kesehatan. Jakarta: Nuha Medika 